Biol. Neonate 1975;27:I-IV

\title{
Contents, Vol. 27, 1975
}

\section{Contents}

Vidyasagar, D. and Chernick, V.: Effect of Metopirone on the Synthesis of Lung Surfactant in Does and Fetal Rabbits 1

Sturman, J.A.; Gaull, G.E., and Räihä, N.C.R.: DNS Synthesis from the (3-Carbon of Serine by Fetal and Mature Human Liver 17

Miller, W,J. and Hubbert, W.T.: Adult Isoantigen and Lectin Reactivity of Bovine Fetal Red Cells 23

Fleischman, A.R.; L·erman, S., Oakes, G.K.; Epstein, M.F.; Chez, R.A., and Mintz, D.H.: Perinatal Primate Parathyroid Hormone Metabolism 40

Edson, J.L.; Hudson, D.G., and Hull, D.: Evidence for Increased Fatty Acid Transfer across the Placenta during a Maternal Fast in Rabbits 50

Hibbard, E.D. and Kenna, A.P.: Valine/Glycine Ratio in Newborn Infants 56

Cser, A. and Milner, R.D.G.: Metabolic and Hormonal Consequences of Exchange

Transfusion via the Umbilical Artery or Vein 61

Hudson, D.G. and Hull, D.: Growth of Adipose Tissue in the Fetal Rabbit 71

Melichar, V.; Rázová, M.; Dyková, H., and Vízek, K.: Effect of Human Chorionic

Gonadotropin on Blood Free Fatty Acids, Glucose and on the Release of Free

Fatty Acids from Subcutaneous Adipose Tissue in Various Groups of Newborns

and Adults 80

Willgerodt, H.; Vízek, K.; Råzovâ, M., and Melichar, V.: Activity of Some Enzymes of

Carbohydrate Metabolism in Human Subcutaneous Adipose Tissue in Newborns, Infants and

Adults. I. Acitivity of Pyruvate Kinase, Lactate Dehydrogenase, Glucose-6-Phosphate

Dehydrogenase and Phosphogluconate Dehydrogenase ... 88

Sadovsky, E.; Matz, D.; Diamant, Y.Z., and Polishuk, W.Z.: Leukocyte Alkaline

Phosphatase in the Newborn 96

Marsland, D.W.; Callahan, B.J., and Shannon, D.C.: The Afferent Vagus and Regulation of Breathing in Response to Inhaled CO2 in Awake Newborn Lambs

Pegg, D.G. and Hook, J.B.: Disappearance of p-Aminohippurate and Inulin from Plasma of Newborn and Adult Rats 108

Garel, J.-M.: Assessment of Fetal Rat Parathyroid Gland Activity during Hypocalcemia Induced by EDTA 115

Nagy, P.; Szabó, I., and Csaba, I.: Changes in the Alkaline Phosphatase Activity of Granulocytes from the First to the Sixth Day of Life in Newborns 121

Kostolányi, G. and Jobst, K.: Electrophoretic Mobility of the Fetal Red Blood Cell . . 125

Roux, J.M.; Jahchan, T., and Fulchignoni, M.C.: Desoxyribonucleic Acid and Pyrimidine Synthesis in the Rat during Intra-Uterine Growth Retardation: Respon

siveness of Several Organs 129

Potier, M.; Dallaire, L·., and Melançon, S.B.: Occurrence and Properties of Fetal

Intestinal Glycosidases (Disaccharidases) in Human Amniotic Fluid 


\section{Contents}

IV

Koo, C; Rogers, S., and Segal, S.: Developmental Aspects of Galactose-1-Phosphate Uridylyltransferase in Rat Intestine 153

Herzfeld, A. and Raper, S.M.: Glutamine Synthetase and Glutamyltransferase in Developing Chick and Rat Tissues 163

Hulsey, T.K.; Palotay, J.L., and Dhindsa, D.S.: Development of the Neonate Opossum

(Didelphis virginiana) 177

Young, M. and Widdowson, E.M.: The Influence of Diets Deficient in Energy, or in Protein, on Conceptus Weight, and the Placental Transfer of a Non-Metabolisable Amino Acid in the Guinea Pig 184

Schindler, A.E. and Wuchter, J.: Studies on Steroids in Urine of the Male Newborn . 192 Egberts, J. and Rethmeier, H.B.: Pressure Volume Curves of Lamb Lungs and the Lecithin-Sphingomyelin Ratios of Lung Fluid 208 Goetze, T.; Franke, H.; Oswald, B.; Schlag, B., and Goetze, E.: Effects of Goat AntiRat Placenta IgG on the in vitro Uptake of 125I-Labeled Human Serum Albumin by the Rat Visceral Yolk Sac 221

Evans, H.E.; Glass, L., and Mandl, L: ai -Antitrypsin Concentration in Amniotic Fluid . 232 Fischer, J.H. and Isselhard, W.: Metabolic Patterns in Several Tissues of Newborn Rabbits during Ischemia 235 Schruefer, J.J.; Haburchak, D.R.; Garlid, K.D., and Seeds, A.E., jr.: Non-Ionic Diffu sion of Pentobarbital across Human Chorion Laeve 251

Bakke, J.L.; Lawrence, N.L.; Bennett, J., and Robinson, S.: Late Effects of Neonatal Undernutrition and Overnutrition on Pituitary-Thyroidal and Gonadal Function . 258 Falorni, A.; Massi-Benedetti, F.; Gallo, G., and Trabalza, N.: Blood Glucose, Serum Insulin and Glucagon Response to Arginine in Premature Infants 270 Rivera, A., jr.; Martinez-de Jesus,-J., and Myers, R.E.: Changes in Tissue Glycogen of Recovering Asphyxiated Newborn Monkeys 278

Murdock, A.I.; Thorgeirsson, S.S.; Rossiger, H., and Davies, D.S.: Serial Measurements of Plasma Half-Lives and Urinary Excretion of Antipyrine in Low-Birth-Weight Infants $\quad 289$

Sybulski, S. and Maughan, G.B.: Umbilical Cord Plasma Estradiol Levels in Relation to Complications of Pregnancy and Newborn and to Cortisol Levels 302

Yang, S.-S.; Chen, Y.-C; Brough, A.J., and Bernstein, J.: Correlation of Head Circum ference and Crown-Rump Length in Newborn Infants. A Potential Indicator of Congenital Maldevelopment 308

Prindull, G.; Prindull, B.; Palti, Z., and Yoffey, J.M.: Phagocytic Cells in Cord Blood .318 Hallman, M. and Raivio, K.I.: Formation of Disaturated Lecithin through the Lysolecithin Pathway in the Lung of the Developing Rabbit 329 Eriksson, M.; Catz, C, and Yaffe, S.J.: Effect of Weanling Malnutrition upon Hepatic Drug Metabolism 339 Greengard, O.: Cortisol Treatment of Neonatal Rats: Effects on Enzymes in Kidney, Liver and Heart 352

Stanescu, V.; Maroteaux, P.; Stanescu, R., and Sobczak, E.: Age-Dependent Change in the Gel-Electrophoretic Pattern of Proteoglycans of Human Growth Cartilage .. 361 
Lansdown, A.B.G.: Histological Observations on Epidermal Development in Fetal Mice Subject to Intrauterine Growth Retardation Due to Maternal Infections with Coxsackievirus B3 '. 368

Varia 375

Author Index 376

Subject Index 377 